るつを思われる酸の生成及び炭素源の程類さ菌の發育 につき研先した。

1）酸の生成をStrain との關倸を見るに最終酸度 恃系統により相違がある。酸の生成は主さこて菌綿の 發声程庭の差臬によるるのと思われるので，炭素源の

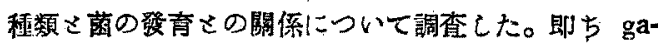
lactose, glucose, lactose, maltose, mannit, sacchalosè, inulin 等を夫々基本液に $1 \%$ の制合に加え $\mathrm{pH}$ 5.5 に調製して行つた結果では, saccharose 最る秀れ maltose, glucose, inulin 之に次き，その他は不適虽 でらる。また galactose, glucose・忹系統により利用の 程度を異にし，或系統には利用されるが他の系統では 利用僄值がなくそその對照が比較的著しい。

2). 白絹病菌のPectinase そ $\mathrm{pH}$ この關係を見る にPectinase 作用は酸性側に於て活發である。白絹病 菌に於汀菌系發育の最適 $\mathrm{pH}$ は 6.0 附近であ.るが，

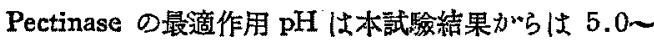
5.5 附近にある樣である。然し $\mathrm{pH} て$ Pectinase の 作用範園は系統により相違がある。

3) Pectinase の作用範圍恃其の系統の生成酸度飞 の關係からみるに，菌の生長量に對する生成酸度より b，垛益の最終酸度さの關係た有し，また $\mathrm{pH}$ 各段階 に於汀る菌系の發亩との關係もある椂で發育 $\mathrm{pH}$ の範 固の廣的るのは一般に Pectinase 作用の $\mathrm{pH}$ の各段 䧑に對し作用力た示した。

4) Pectinase作用の適温1士 $40^{\circ} \mathrm{C}$ 附近である。2 $0^{\circ} \mathrm{C}$ 以下或恃 $60^{\circ} \mathrm{C}$ 以上にて殆に゙作用性認力られない。

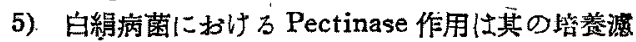
液に於て强く菌體粉末の抽出液に於てはその作用程度 性著しく弱い頙向先示した。 (岡山煙草試監場)

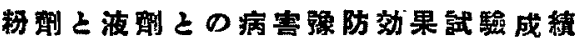

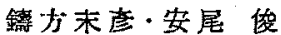

近時㤟藥の撒粉が液劑橵布さ同樣に勃果があり，北 米では賽用化されている。果して撒粉が氣候風土の異 なる我國でいがる効果死あげ得るが早急に檢討す

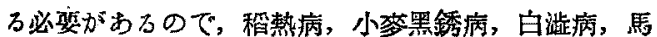
鈴著疾病，搵豆赤色㾏點病，柿角斑性落葉病について 圈場試略长行つた。

(1) 稳熱病に對してポルドウ粉劑はポルドヴ液劑に 劣らない効果があるが，菜害は液劑より甚だしい。(2)

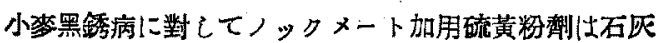
硫黄合制に比し效果が棬れていたが，硫黄粉劑(50\%) 恃多少劣亏。ノックメートの液劑も石灰硫黄合劑に劣

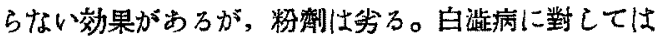

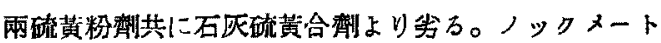
は液粉兩娈共に，石戻硫黄合劑上り效力が優れている

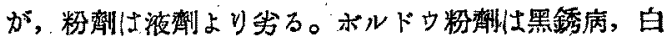

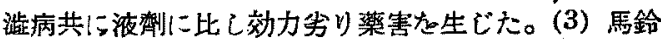

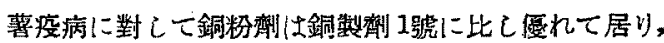

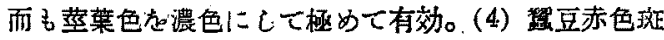

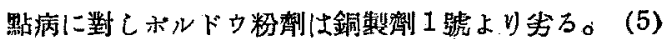
柿玟點性落葉病に對して銅粉制，ノックメート粉劑共 にボルドー液に比し効力が劣つた。

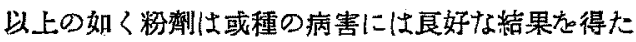
が，液弈よりる分つているもの气少くない。

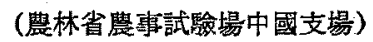

\section{4 年度秋季關東部會}

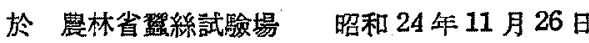

Abstracts of Papers presented at the Meeting of Kanto Division, held on November 26, 1949, at the National Sericultural Experiment Station, Tokyo.

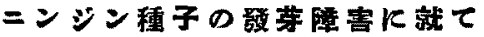 \\ 想 井 義 郎}

ニンシン種子の表面には Alternaria radicina の 胞子が附着して居ら場合が多く見られるが：二の菌は $20 \sim 30^{\circ} \mathrm{C}$ の間に於てはニンシンの發芽障害に關係が 少く, 0.1 及び $0.2 \%$ ウスプルン,メルクロン, 1 及

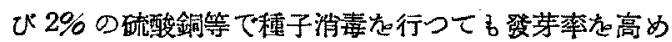
る効果が殆しビない。ニンジンの肧を解剖的に取出し て LUYET 氏生死染分法㤂試みるさ，肧の全然死亡己 て居るもの, 肧の子葉, 肧軸の部分が死亡して居る b の等，種々の段階が見られ，天れによつて肧の發育が 滿足に出來す，或は幼根のみ出して止万方の，又幼根 の伸長惡い方の等の發芽障害の段階加見られる。この

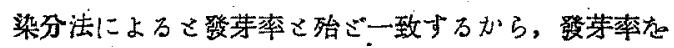
簡單に調查するここる出來る。肧の死亡率は種子の大 中小に估つて異り，各々 14.7,17.1,28.0\% そなつて， 小粒の方が死亡率が高くなつていた。種子を一度吸 水後乾燥させた區では, 吸水させ澏に比較して压死 亡率が 14\% 近く高くなる㥧向が見られた。種子の登 熟度合に依つてる阫死亡率が異るようで，本校围場に 於て 8 月上，中，下旬に探種した種子では 8 月上旬探 種區の死亡率が一潘高がた。(新渴農林楞門舉校) 


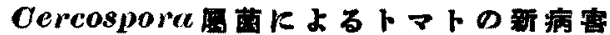

U田鰝 $\rightarrow$

筆者は 1948 年 8 月岥皁縣下に於て,トマト萧に葉徽

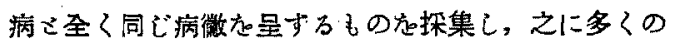
Cercospora 罢菌の胞子丸認めたので分離沶荃及び同 定を試みた。香月氏によれば整及び福岡祭下にる相

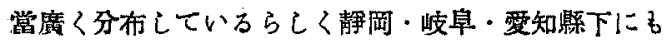
認められ分布は廣いものこ思われる。東海地方では 7 月中旬頃よりトマトの生奇末期まで發病綘け，特に 末期に著しい。病原菌は香月氏により發表されたC. $r$ cospora diffusa ELL. et Ev. ( $ト$ マ煤徽病症狀) を全く同一であるこをを知つたが，病原菌の記载につ いては捛子梗の隔膜の有無汃問題であり，香月氏ょり Dr. CHUPP に同定杂传賴中である。

病徵は葉徽病さ酷似こ肉眼では區別するここが因難 である。病名を谋徽病 (Cercospora leaf mold) さ提 唱寸方。

分生胞子の發芽忙最適 $26^{\circ} \mathrm{C}$ 附近, 最高 $36^{\circ} \mathrm{C}$ 附近 である。分生胞子の致死温度は $56^{\circ} \mathrm{C}$ で 5 分を 10 分の 閒にあり，菌系では $48^{\circ} \mathrm{C} て ゙$ 同じく 5 分さ 10 分の間に

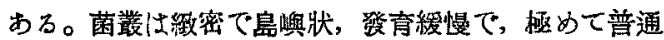
にSaltation 九起す。培蔡基上に於ける分生胞子の形

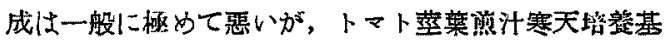

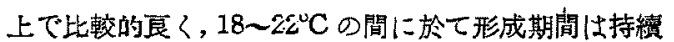
$\varepsilon$, 最 8 艮好である。1\% 蔗糖加用馬鉿著息计寒天培 裳基上に於て，菌系發育の最適温度は $26 \sim 28^{\circ} \mathrm{C}$ の間， 最高温度は $34 \sim 36^{\circ} \mathrm{C}$ の間である。分生胞子は乾煤状 態では 12 月上旬上り瑟年 6 月下旬まで生活力を有す 万が，過濕の狀態では約 40 日で殆んご生活力奆失う。 即占分生胞子は乾煤狀熊に保たれ〉代㕸年の第一次傳 染源さなり得るものさ思われる。トマト菌に對する接 種は極めて因踓であつたが，一回げり成功し，典型的 な病徵を呈し菌を再分離し得た。發病環境は未だ不明 であるが，通風等の條件が大きく影響するようである。 品種閒耐病性の差性顯著でばないが，本年 53 品種に 對する自然發病狀態若觀察した結果ではドワーフスト ーン，マーグローブ及び樹势の强い $F_{1}$ 少耐病性の强 い㑯向が見られた。率劑の分生胞子發第に對する抑制 作用はりリドは甚げ微弱であるが，ボルドー液は著し く、フアーメートザーレートが之に次ぐ。

(農林省園藝試羷場)

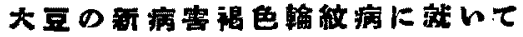

柳、下 浩

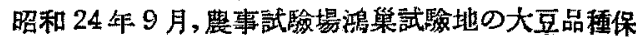

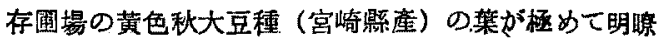

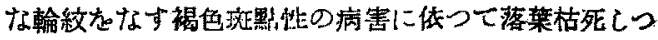
〉あちの大發見し，檢镜の結果，Cercospora 别 Het:

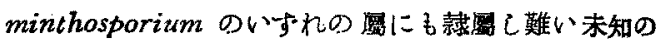
菌龙認め心。

病菌㤂分離，大豆に接種した所本菌は鹪がなくてる

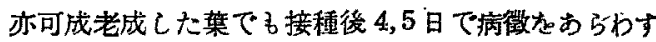

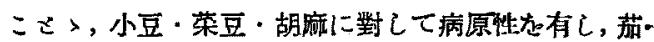
馬鈴薯・ムクダには有しないここ雐めた。

病菌の分生子梗代細長筍筒形，黑裼色，多〈は鋠生，

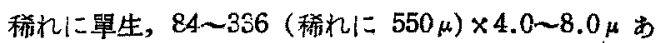
$v$, 濕潤な狀熊で分生胞子脫落後分生子梗が第 2 次生

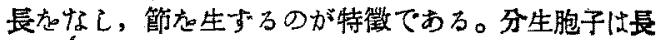
倒棍棒狀で一方に䋛曲するるの多く，時に長筒形む v，灰白色，淡黃色，大さ $2.6 \sim 218.4 \times 5.2 \sim 19.5 \mu$,

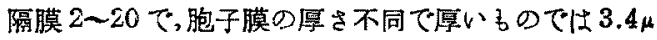
に澾す。多く單生稀れに镍生する。此の際には2 胞子 間及び分生子梗この澗に isthmus灷生ずらの゙特徽で ある。

小豆前汁寒天塔愁基上で培盖するこ 7,8 日で分生胞 子志形成与万。本菌の發育鼠適温度纴 $25 \sim 26^{\circ} \mathrm{C}$ 附近 けある。

本菌は後藤（1942）が記載した，ムクグの褐疼病菌 Corynespora Hibisci GoTO 飞形熊上酷似している。 1906 年に Güssow が創設した Coryn:spora 摆に就 いては倘翼諭なしさば云えないが，筆者は，分生子梗 の特異な生長法に依つて生ずる nodes, 及び前記の isthmus Ф存在上V), 此れ売 Cercospora 及び Hel-

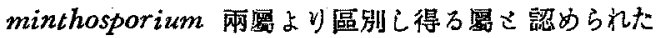
後藤氏の說に梖意し，本菌㤂 Corynespora sp. こ同定 寸る。

矮化病（新释）にっんて

$$
\text { 日高醇 }
$$

矮化病は昭和 10 年頃より時々瀨戸內海沿岸地方で 探集せられてきたるのであるが，大した被害がなが たので問題にならなかつた。近年次第に東渐の㥧向が あり，昭和 24 年には神奈川悲然で大發生し，群馬·苂 城の兩縣にる探集せら机るようになつた。筆者はこの バイラス病の防除法な速加に解決するために研热調查 隊㤂組織して研笕にあたつた。このバイラス病は苗床 
の床土の消毒によつて防除しうる。霓酹の1例では床

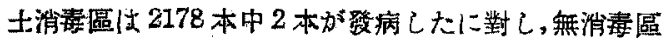
は2178 本中956本の發病た見た。病徴はは仕葉脈

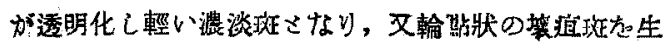

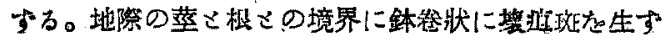

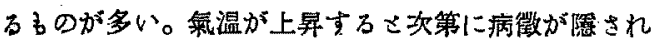
てくる。しかて上記の病徽はかくされても坐りこんだ はうに矮化した狀態け回復ざず，開花期には花だけは 開いて結實する。種子傅投はしない。染沫接種が可能

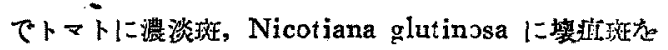
形成する。乾燥するて不活性化する。

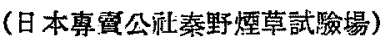

\section{箸一バイラスによるトマトの streakK武いて}

小室脿 雄

昭和 24 年 6 月東京世田谷で自家茶園のトマト(品種

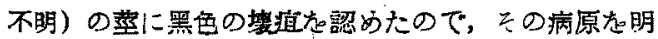
らかにするために實驗是行つた。病徽は植付初期には 全然認め引れなかつたが，着果し始める比になりあら

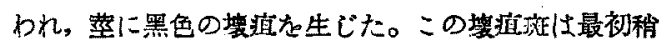
細長い小珓であつたが，欢第に大きくなり，長いるの では 15〜20 cm の條斑をなる。これは䈎柯にもあら われたが，葉には枯死斑，輸點なごの病徽た生じなが

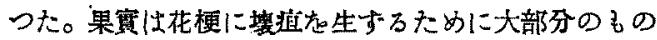
は落果してしまう。條斑势㨁がきだはげしくない頃に 着果したるのの果皮に nectotic spot も見られた。ト マト(ポンデローザ，世界一）、トルニタバ Nico. tiana tabacum, Datura tatura, ナス (畺黑),アカ ザ等にカーポランダム法で接種するを何れる獨特の病 徵たおらわした所から，本病原はバイラスである事を 知つた。本バイラスは Lycopersicum virus 1 又は double streak virus の何れが推定せられるが、ト ルロタバコ, Datura に對する反應，モモアカアブラ ムシによる傅搬試驗は院件の結果，物理的特性（不活 性温庤 $80^{\circ} \mathrm{C}( \pm)$ ，稀釋限度 $30,6 \mathrm{CO}$ 倍 $( \pm)$ ，耐保存性 128 日以上)等加名本バイスが Lycopersicum virus 1 に近い事㤂知つた。HOLMES (1959)!よるて Lycopersicum virus 1 Nicotiana virus 10 strain であるをされているが，トマトモザイク病がら分離し た Nicotiana virus 1 を本バイラス规々トルコタバ コ,トマト，ナスに接種した所その病徴が兩者の間で 異る事を認めたので：この兩バイラスの間で免疫接種 試驗芯行つた所、本バイラスに對して Nicotiana virus 1 は Protective action があり，兩者は近緣の るのである事が認められた。以上の點芯綜合とて本心 イラスは SMITH (1937) の分類に從うこ Lycopersicum virus 1. HoLuES (1989) によるを Marmar tabaci var canad.nse に根當するこ思われる。

(東京大學農學部)

\section{馬输量モサイク病の初感染に於ける} 橃病，特に收量につんて

$$
\text { 加 藤 美 文 }
$$

東京に於りる春作栽培ではモザイク病の初感染に よる發病は 5 月下旬，多くは 6 月上旬以後に見引れる。

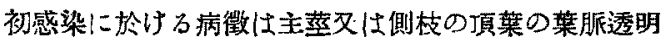
化〜モザィク斑紋をして現われる。6月上旬は開花前 期で, 塊龿の肥大が始きる時期に根賞ずる。

品種紅丸九用いて，各株繁發病日飞，最終堀取時 に於ける各株矮の塊荎收量こた調查した。5月19日〜 6 月 2 日の病株では, 平均收量 $200 \mathrm{~g}, 6$ 月 6 日以後 の發病株で忙平均收量 $330 \mathrm{~g}$ で，6月 2 日〜6日の間 に大きな差が見られ，この差は統計的に有意であつた。 6 月 6 日以後登病株の收量は，健全株に比して有意な 差がなかつた。すなわち6月2日以前の發病株でば,

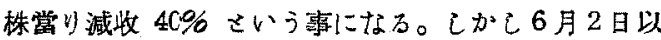
㮍の發病株數はこの武驗の場合は全株數の1/6にすき なかいた。この㮈に早期の感染が多くない條件では，

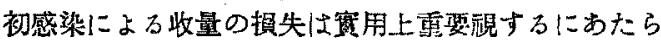
ない事になる。

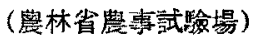

\section{モモアカプブムシによるジガイモ Yハイラスの媒介}

\section{葛西武雄}

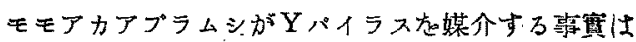
多くの研焱者によつて報告されているが，その傅染力

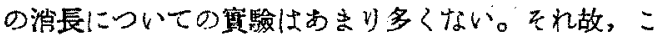
のアブラムシが本バイラスの傳染能力た。㹲得し，或仕 これを失う條件につき2,3の賽驗試みた。供試植物 は全てタバコ・ホワイトバーレー䅗で, 植物 1 個噇宛 のアブラムシの数は 1 匹るし，各赛歌は 3 国繰返した。 この結果無害アブラムシは症病植物を 5 分閐加害する

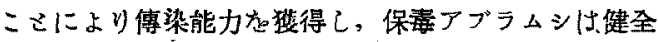

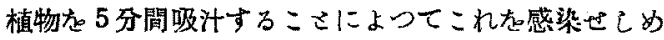
るここが出來る。爻ブラムシのバイラス保有期間は， 保毒アブラムシたがラス器具內に罊離した場合は 3 時

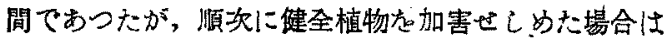


5 分さ15唯さの間で傳染力た失つた。

WATSON \& ROBERTS (1959) はYバイラスたたの 媒介昆䖪體內で永存しない所諎 non-persistent type

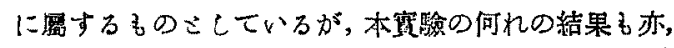
それ去寒附けっ證據をなるものである。

(東京大學㖘學部)

\section{ジヤかイモYバイラスによるジがれ 葉上の Loeal Lesionk 就て}

鼠 家 清

ジヤがイモの葉にYバイラス接種するを接種悉上 に局部的に Necrotic Spots 在澤杵生ずる。Xパイラ スを接種しては、かうる Local Lesionは現われない。 所がイハイラスにXパイラスた混合してシャがイモに 接種するこ，Yパイラスを單獨で接種するより L Local Lesionの形式は促進され，潜伏期間が短〉なる。この 場合 Xパイラスをとて貫林一號體內に含まれる病原性 の强い系統壳混合するさ，紅丸の體內に含きれる病原 性の弱い系統を湦含した場合よりも潜伏期間が更に短 くなつた。尚、この實噞にはXハィラスに感染してい

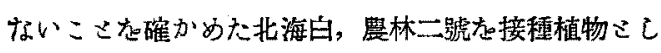
て用いた。

次に著者はトライアンフ種のシャガイもに2 䅜颗の

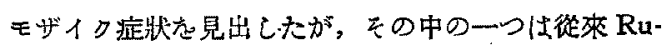
gose Mosaic こされている症狀飞一致し，他性葉が Crinkle 狀で明暸な Mottling 老示し, 葉脈及び脈間 に何等 Necrosis が見られないるのであつた。この兩 者加らのハイラスについて，シャガモの接㮔葉上の Local Lesion の形成力太比較した。北海白に接種し たこきけ何れのバイラマ Local Lesionを形成した。 然しトライアンフに接種するき，Rugose Mosaic 症 状株のバイラスはLocal Lesion虑形成したが, Crinkle 症狀株のバイラスでは Local Lésion の形成が見られ なかつた。このここはYバイラスによるLocal Lesion

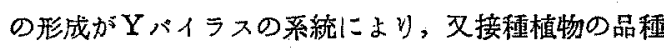
にょつて支配されるこを长示すものであるう。但し， トライアンフに接種して Local Lesion を起さなかつ たバイラスがYバイラスの系統であるが, 或いは別 個のバイラス，例えばAバイラスに近いものであるが に就いては今後明加にする必恐がある。

(軎京大學農學部)

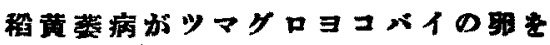 通じて㑭染しない事に就いて}

新 海昭

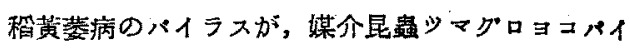

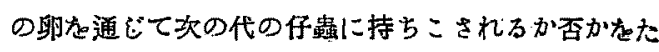

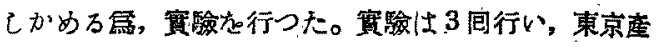
のツマグロヨコバイた供試した。供試親蜈によつて座

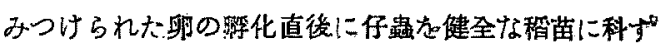
方法は，瞕士 (’39) が稻菱縮病バイラスの經卵傅染の 惯驗に用いた方法た用いた。

第 1 赛羷は豫備的なもので，保毒崔蟲2頭から産ま れた仔蟲 5 頭㤂得て 1 万至 3 ヶ月に亘つて 5 万至10日

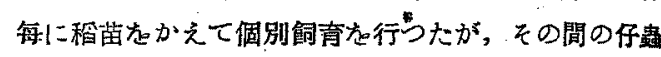
が吸つた僽苗は全て發病しながつた。第 2 惯驗は，兩 親共に保毒の4例がら仔䖪·1C6䫒を得，母親の子保莓

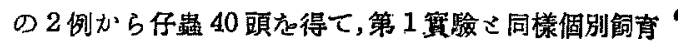
た 1 乃至 3 ケ月つょけたが，其の間に仔蟲の飼充に供

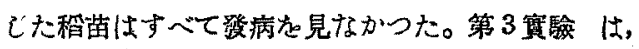
病稻のみで 3 代つぐけて，飼育した雌蟲れ親として用 い,この蟲が1日の間に産んだ仔蟲の個別飼育たした。 産卵鲎待バイラスの傳染能力たるつていた甠蟲 18 頭

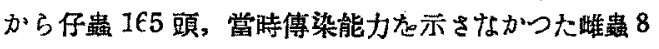

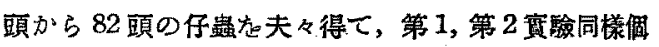

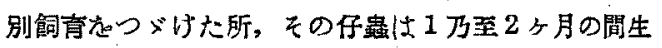
き殘つたが，吸りれた积はすへて發病しながた。

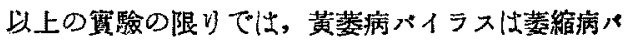
イラスを異り，ッマグロヨコバイの卵さ通じては傳染 しないを云える。同じストックの蟲で病稻圭吸りさた まのは，高い率で傳染能力たあらわした。

（啀林省震事武匳堨）

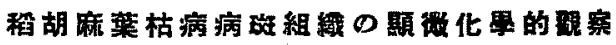

三澤 正 生

稻胡麻葉枯病々㹩組糡の各種試樂に對する反應を， 影微化學的に觀察こた結果な簡單に報告する。人工接 䅜した稻の葉の病斑を徒手により縦断切片をして供試 した。總へて生組織である。

表中の嚓死部は, 病斑中央の濃褐色部太示し; 中毒 部さは，烄死部周緣の穆色部え示するのである。

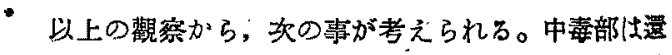
元的狀態にある $(1,2,3)$, Indophenoloxydase, Peroxydase $の$ 作用が强い $(4,5,7)$ ，特に中毒部飞壤死部 この接際部にNADI 反怎が强く發現する。フェノール 類・アミノ酸数の分布が漉原である $(7,8,9,10)$ 。次に 


\begin{tabular}{|c|c|c|c|}
\hline 反熦丈は試樂 & 健全部 & 中毒部 & 填死部 \\
\hline 1. $\mathrm{KMnO}_{4}$ & - & + & ? \\
\hline 2. Eisencyan 像 & - & + & \\
\hline 3. Rongalitweiss & + & - & \\
\hline 4. NAD1 反鹰 & \pm & $H$ & \\
\hline 5. Pyrogallol $+\mathrm{H}_{2} \mathrm{O}_{4}$ & + & H & \\
\hline 6. Benzidin $+\mathrm{H}_{2} \mathrm{O}_{2}$ & + & +1 & \\
\hline 7. MILLON 反雔 & + & $H$ & \\
\hline 8. EHRLICH 反槱 & - & $t$ & \\
\hline 9. Diago 反萑 & - & + & \\
\hline 10. BAYER 反焦 & - & + & \\
\hline
\end{tabular}

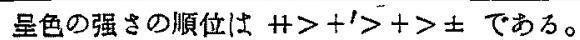

$$
\text { 一は無反㮣。 }
$$

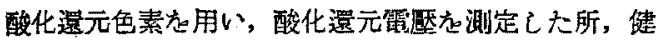
全部は $\mathrm{rH}_{2}$ が 14.4 附近，中毒部は 5.2 或は去れよ り稍低い所であるここが觀察された。壤死部は着你濃

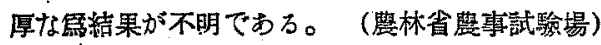

\section{菃いもち病砤の類型}

$$
\text { 小野小三郎 }
$$

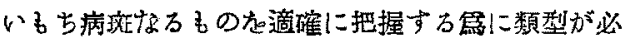
要をされる。この類型するこ云うこをは實用的な防除 の場面におつても重嫶な意味たもつものである。

類型充なすには病斑を澤山集め：これた同時に比較 檢討するこてが必要である。そこで私はパルサム封絾 標本か用いるこににした（病集のバルサム封絾保存法

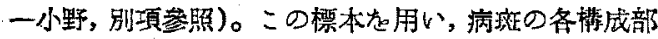

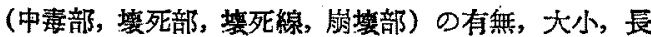
短，色彩及び蕃體の有無，多少等によつて病玟を次の 如〈奇類した。

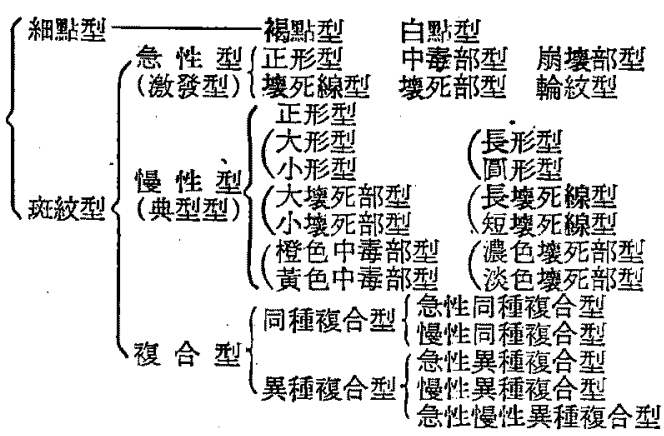

この中急性型さ愠性型をの何れも正形型によつて比 較え試みるこ，丽者の間には病斑の形狀，色彩，各擭 成部の有無, 病斑の現われ方及び病斑上の菌體等にお いて甚げしい善加ある。

これらの型㤷品種，及び環境によつて表われ方を異 にこている。

型を知るこさによつて，立れず經過し來つた環境 な想像するここの出來っ場台もあり，又之の後の病害
の進展狀況危もある程度豫察するこさる出來る。又施

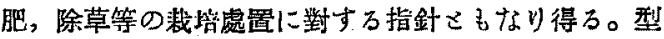
の異かに從つて防除法の選擇にも差走生じ；，（處置 の危を姴するか否かの判定に役立つわけである。

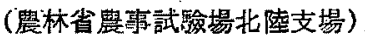

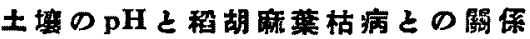

烊柿弘

稻胡病葉枯病の發生に土壤の $\mathrm{pH}$ が如何に關係する かについて三三武擥をした。水田では土翌の pHは土 壊が還元狀態になるに件つて中性の方向に動くため， 有械物多〈監基の少ない泥炭地等の外は餘り問題にな らないので，一應畑作狀熊で試驗をした。

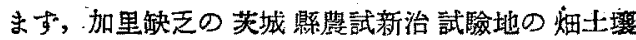
(pH5.5)には硫酸及ざ監酸で $\mathrm{pH}$ なさく，炭酸石灰 及ひ炭酸りーダで，々の $\mathrm{pH}$ 大大にして pH 3.9〜6.9 の間で陸稻身代起をまき，發病調查をした處無加里區 では硫酸，監酸を加えて $\mathrm{pH}$ を小さくした場合は $\mathrm{pH}$ が甚しく小さく( $\mathrm{pH} 3.9 \sim 4.0)$ なるる菜におりっ加里 缺乏症狀は標準區（pH 5.5）より罴しくなるこ共に胡

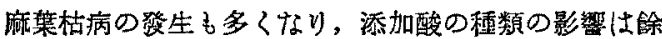
り認められなかつた。しかし， $\mathrm{pH}$ を大にした場合は

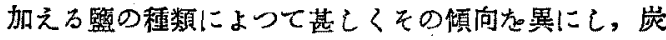
酸ソーダた加えて $\mathrm{pH}$ 危戀えた場合は $\mathrm{pH}$ の㙁大に 伴つて天の生姢も標準區より宠好さなり，加里缺之症 狀まあらりれず，胡症葉枯病も輕微こなつたが孷酸石 灰㤂用いた場合は逆にその添加量の謃加に よっ $\mathrm{pH}$ 算大に件つて生䏍は不死さなり， 加里缺乏症狀飞共に胡麻葉枯病も甚しく管

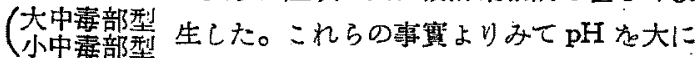

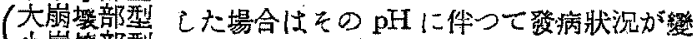
小崩等部型 (輪紋型 兩側濃厚型

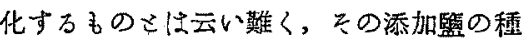
類によつて著しくその影響が異なり，リー 監では發病㤂減少せしめ，石灰監では逆 に筧加せしめる。こ放もっこれらの關係は 加里缺之症狀の發現こ平行關係が認められ

た。一方，加里を施用した場合は $\mathrm{pH} の$ 影签或は酸並

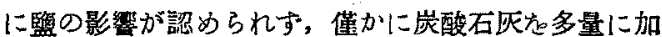

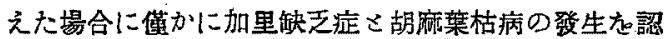
めたにすぎなかつた。

この原因起考察してみるに，pH功極端に小さくな

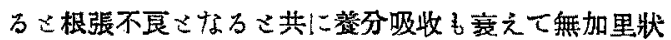
態では施用された窒素のみ多く吸收されて天然供給量 に依存する加里の吸收が少なく，加里缺之症狀の發現 
と共に胡廊等枯病を誘發するものと考えられる。從つ て加里去施用すればその pHに關係なく，その發生は

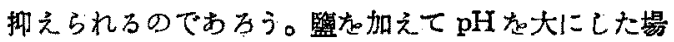

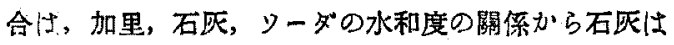
加里の吸收を抑之て盒々加里缺乏症並に胡㾋葉枱病の

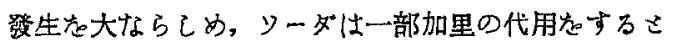
共に加里の吸收え。容易にして，その發生え少なからし め, pH は䋡り關係しないものこ考えられる。從つて 石灰な施用しても加里さえ施用してがげばその惡影留 な除きうるるのこ考えられる。水田における消石灰施

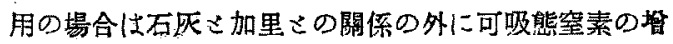
加も加わつて佥々加里缺乏症の發現主に胡麻葉枯病の 發生㤂助長す万㥧向が認め引れた。

（農事試䛗場北陸支場）

\section{程赤枯病と加里との關保}

岡本 弘

稻の赤枯病は水田の酸素不足の場合に相の障害によ つて繁生する生理障害さ云われているが，この病徴が 加里缺乏症に似ている點常發地帶加比較的加里缺之地 帶に多いここはごより，加里この關係が深いるのを考 えられたので、ニの關係を調査した。

普通载坮では赤枯病の發生しない當北陸支場內の水

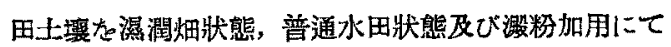

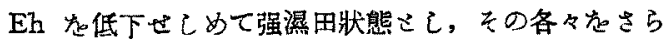
に無加里區, 加里施用區に分つて稻各品種の赤枯病發 生狀況を調查した處敩國, 新 2 號, 林 3 號は無加里 澱粉加用區にのみ發生し, 涮粉加用區にても加里施用 區には發生九認めなかつた。しかし陸稻壁林 21 號で は普通水田狀態無加里區にも發生を認めた。二の點よ yみて赤枯病は土中酸素の不足（Eh D低下）の外に 加里五大〉關係するここが判る。赤枯病はEh の低 い場合の外に泥岸地なミ゙で㥛端に有機酸の出來た場合

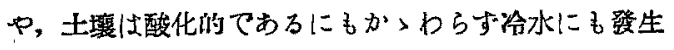
するが、これも加里の施用によつて輕減しえた。この 㧼に赤枯病けその葉の病徴立和里の施用によつてそ の發生が輕减される點よりみて體內成分は加里缺忌症 狀であるうこ推定されたのであるが，事實との成分地 調查してみるる加里含量がなく窒素含量多く， $\mathrm{K}_{2} \mathrm{O} / \mathrm{N}$ は健全株に比して小さく明らかに加里缺灭症であるこ こがわかる。從つて土翌中に窒素の多い程, 加里の少 ない程赤枯病即ち加里缺乏症は起りやすいこをにな る。土管試驗の結果もその通りの結果九示した。久烣 酸ての關係は過橉酸での試驗ではとの量が極端に多く
ない場合は餘り影需しない。

加里がその發生に關係するのであるから，加里缺之 土褧ではおこりやすい事になるが，ポット試騟の結果 明らかに二の事筧危示した。及，一方酸素不足が一 原因にもなるもので，陸䔣の如き，酸素娶求度の高い （Ehの大きいの芯好む）品種は特におこりやすく，混

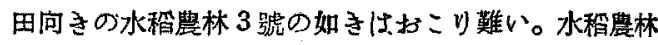
1 號, 要國系品種なごはおこりやすい。及, 陸稳の品 程閒差異大調查してみるこ加里缺症のおこりやすい 品種は赤枯病も亦おこりやすい結果た示したが、これ は兩者が生理的には同一のものであるから罍然の結果 である。

土壤の Eh が低下した場合加里缺乏症（赤枯病）の 發生しや寸い原因は $\mathrm{Eh}$ が低下するこ土中の可給態加 里の減少するこでか一つの原因になつているこ共に根

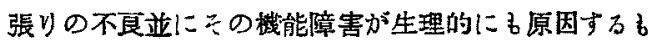
のを思われる。この樣に赤枯病の發生法 $\mathrm{Eh} の$ 低い: こが原因ではおるが，Eh が低下しつ〉あろ狀態るさ らに大きく影響することは二三のポット試䀫がらる推 定された。有被酸や冷水による加里缺乏症の發生の如 きは主さして根張りの不足並にその機能障害が大きな 原因を思わ㣗万。

(莀雪試驗場北陸支場)

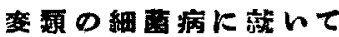 \\ 向零夫・土屋行夫}

本類の細菌病は昭和 22 年頃から瀬戸內海沿岸地帶 及び東海地方の鹰い籍園に發生し其の被害が激基さな り，現在では關東以西の各地に擴がつている。极病は

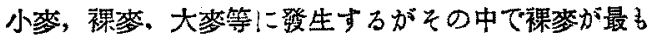

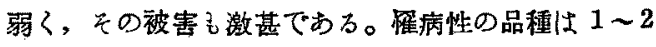
の例外龙のぞけば殆んで日本在來種に限ざられている 事飞發生の年次加淺いここ加考えるこ本病は或る年 代に外國から鐱人されたものて思门れる。

大麦及び裸荾は葉，葉鞘，䬣，節間が侵され，葉及 び葉鞘では帶黑チョコレート色の條玨え生ざ，節部で

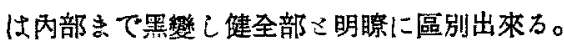

小麥では節間及び節の部分が侵され，そのためこの 節に生ずっ葉は悉く黄變する。病名は帒の黑節病或は 黑條病さ命各したい。病原細菌の細菌學的一般性状仕 含水炭素の分解力及び温度さの關係在除けば，米國で ELLIOTT 氏が記载している燕货の (Bacterial stripe blight）條枯病の病原細菌を全く一致ずす。恐らく同 一の病原細菌 (Bact. striafaciens) 加或は夫れの綎種 そ思りれる。本病原細菌は各種麥種子に附着こて收程 
期より 9 月ー 11月の播程期!二至るまで容易に生存 $C$, 種子によつて遠力に運ばれ，また保菌程子によつて第 1 次發生源となる。越夏する菌の制合は小桨種子が最 も惡くて死減も早いが，裸來の種子では最も長く生存 方る。皮表では强乾燥氣中では100\%生存すかが，濕 度が $60 \%$ 以上では11月までに全部死隇し, 裸茜で は $80 \%$ 以上の蒸氣中では死减するが，夫れ以下では $100 \%$ 生存すっ。小装では $49 \%$ の湿度の氣中で最る はがく生存し，それょり乾喍するも，办缹度を増加す 万生活力九減少己１1 月までに全く死堿する。種子 は必らす水銀劑等に浸漬して消毒したものた使用する

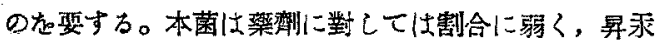
液の 1000 -1600 倍で 1 分以內, 晒粉液で生 16C0〜 3200 倍で 3 4 分, ホルマリンは殺菌力弱く, 1C0 200 倍で 40 分, 石岸酸液は，50 100 倍で 1 分で死 减する。りスプルン液では 1060 倍で 3 分間,メルク ロン液では 1000 倍で 1 分間で死减する。

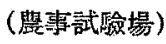

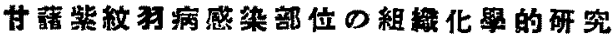 (I) 䫘微化學的觀察}

鈴木直治・篮并久三・荒木隆男

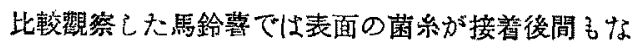
〈侵入座な作り束狀信入菌系は木梌層細胞縫合部か容 易に裂開して柔組織に洼し此所で侵人を阻止される。 此の間木栓層は代化しない，層の數が速に塯し 10 層

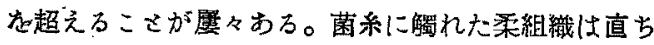

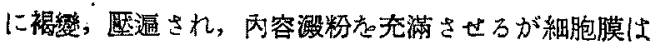
溶解しない。此の部分は MILLON 反照强く陽愔, Diazo 反應紅色で Phenol 化合物の集程が推定され る。甘諸では表面に菌紡接着してから表四上に菖延 するのに2〜3 分在貫し，密に全面起覆つて後侵人

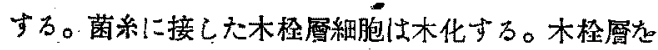
徐々!侵人するが柔組織に達するこ速に天の細胞膜圭

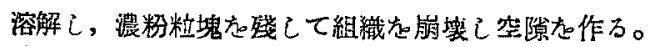
此の部分の $\mathrm{pH}$ は 4.4-4.8 で有機酸の生成が想像さ れる。 $\mathrm{FeCl}_{3}$ で綠色, MILLON 反应微に陽性:, Diazo 反隼紅色。別に條件により敕腐坫起す場合さ尾端より

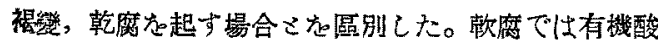
の生成九認め定性反應の結果安息香酸さ推定した。，乾

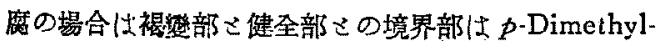
aminobenzaldehyd (酸性) で强く紅紫色に發色する。 此の呈色は原形質分離した原形質の中に現れる。組織 の水蒸氣蒸溜液よりェーテッ抽出によつて得られる黃
色油狀物質は本反㮣を呈し，又 HOPKIAS-COLE 反缺 陽性である。從つてインドール化合物さ推定されるが 柾浦氏のイポメアマロンこ同じ操作で得られる㼭, 此 その關聯は檢討中である。此の部分に接し健圣部侧に アルカリ性で青綠色, $\mathrm{FeCl}_{3}$ で黑綠色, $\mathrm{K}_{2} \mathrm{Cr}_{2} \mathrm{O}_{7}$ で褐

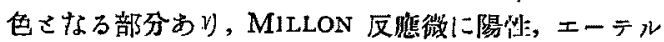

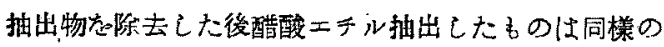
反㫿苾呈する點から小施氏のタンニン系物質さ想像さ れる。

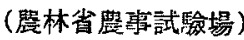

\section{桃崖㾇病枝の生理作用につんて} 北島骤

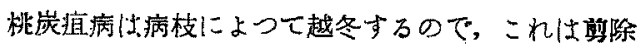
となければならない。併し落葉後，2月までせ之の判 別が困難であるので洛葉前に行うのであるが, これの

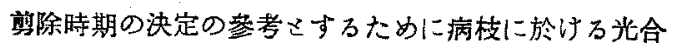
成能力た浿定し，更に同化及ざ呼吸に關係のあ万等緣 素, 酵素颣について定量等行なつた。電導度式微量炭 酸瓦斯測定裝置により, 病亲飞健全案この宸酸瓦斯量 茟测定して計算により光合成による炭水化物（葡萄糖。 こして算出）の量と呼吸によるその消耗をた求めた。 病菜は健全葉に較べて共に旺盛であり，特に呼吸作用 の增加加認められたが, 合成て消耗この炭水化物量の 差は网者間に著しい差は認められなかつた。

以上の測定に用いた莱についてクロロフィールの定 量を行なつたが，病葉は $0.216 \%$ ，健全萎は $0.207 \%$

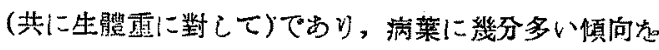

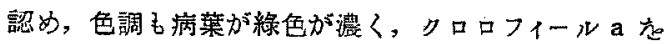
多く含しものさ認められた。酵素類の中で检出し得た ものはヘルカキシダーゼ,カタラーゼ，エムルシンで, 病葉け健全葉に較べィルカキシダーゼが少なく，カタ ラーゼは多く、エムルシンは少なかつた。病枝の㷛が 撩くのは，桃炭疽病菌が一種の酵素樣物筫去分泌して その刺戟によるものらしく，菌によろ寄主體內の De-

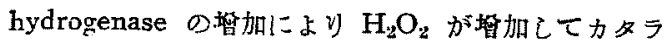

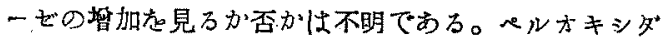
一ゼ唡葉に少なかつたが、これはクロロフィールの 含量さ關係古るものさ思われる。

陮病枝は二の測定時期（9月～10月）には呼吸量多 く，特に夜間に於り゙る消耗が多いので，9月までにば

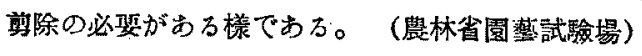




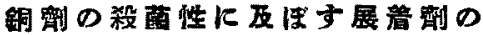
影紫に就的て(豫赧)

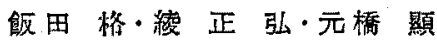

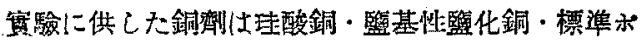
ルドウ液の 3 種, 展着劑は脂肪酸エチルェステル・ア ルギン酸りー艾・スルホン酸りーダ・カゼイン・アビ エチン酸加里の5㮔で，銅剂の濃度は銅さして珪酸銅 及び鹽基性監化銅は $0.05 \%$ ，標集ホルドウ液は $0.02 \%$

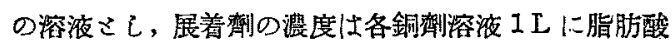

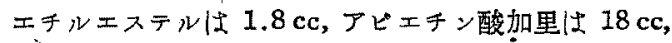

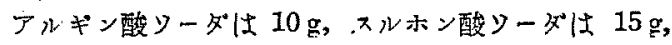
カゼインはJ0g 艻加えたるのでそれぞれの溶液走

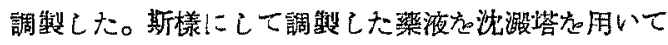
、スライド缩子に撒布した後 $20 〜 25^{\circ} \mathrm{C}$ の室温に 4 時間 放置乾燥したものを，同樣にして 4 時間放置乾燥した スライド硝子丸 10 度に傾斜さざて降水量約 $30 \mathrm{~mm}$ さ $90 \mathrm{~mm}$ とに棺當する雨水た低歷にしたエヤコンプレッ サーで貲霧洗條後, $28^{\circ} \mathrm{C}$ の定温器に人れ水滴㤂乾燥さ せたものに就いて稻胡庥葉枯病菌の分生胞子添濁液芯 點滴己その發第步合㤂檢した。結果代藥湾撒布後乾燥

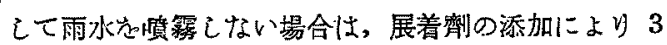
種の銅劑を通して添加しないるのに比し殺菌性が劣つ て居太。展着劑の種類に上万殺菌佌の差異は，アルギ ・ン酸ソーダは他の 4 種より多少劣つて居り，4種の差 異は殆んご見られなかつた。降水量 $30 \mathrm{~mm}$ に相賞す る雨水を噴霧した場合は展着㵑の添加によつて殺菌性 が優つて居た。展着劑間に於ける差異はアルギン酸り 一ダ・スルホン酸りーダが多少劣り，他の3種は同程 度であつた。更に雨水の量莡管加した場合に就いて見 ると，全體に亘つて相當高い發芽率な示し，殊に展着 㰾在添加しない場合は $90 \%$ 以上の發芽率を示して殆 んご殺菌性が見られない。馓着劑添加の場合にばアル ギン酸が最る劣り次でスルホン酸で，他の 3 䅜は多少 殺菌性が認められた。

これら結果资發芽率に基いて少教例による分析芯行
うを，雨水を噴露しない場含は展着制の添加の有無に よる殺菌性の差の有意泩が認められ，降水量 $30 \mathrm{~mm}$

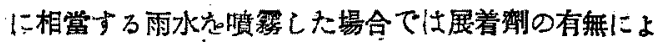
る殺菌性の差異の有意性が認的られ，90 mm 噴露した 場合は展着劑の有無による殺菌珄並に展着制の種類に

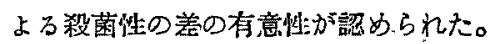

(農林省豊藥检查所)

\section{馬鉿缼の疼病抵抗性之葉液 滲涹涯との關你}

鈴木橋雄・憘木 嶨・村野久富

疫病感要性品種男佷及认゙比較的抵抗性の紅丸れ供用 己て原形質分離劑长坦加こた以外，前年を全く同一方

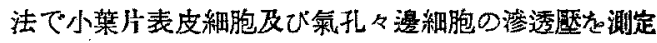
した。原形質分離劑さしては蔗糖つ外 $\mathrm{KCl} 及 ひ ゙ \mathrm{KNO}_{3}$ を用いた。

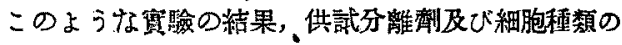

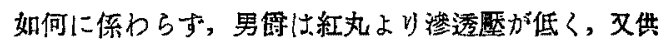
試兩品種共に分離劑の如何を問わず，氣孔々䕗細胞は

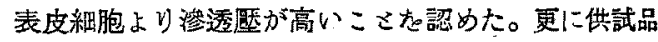

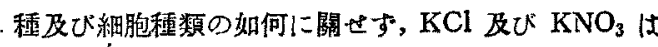

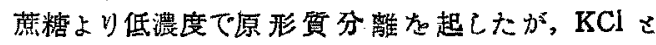
$\mathrm{KNO}_{3}$ この間には著しい差異がみられなかつた。

上述のような實羷結果から考察するを，少くこる著

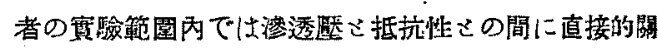

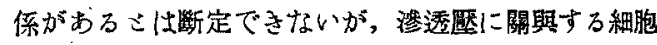
內容さ云うような間接的關係が存在するものさ思われ ろ。この點については目下賽踰中である。

\section{雅大根に對する有超蚵题の乘来狀況を 大㮛モサイク病發病行に就的て 白湠堅一

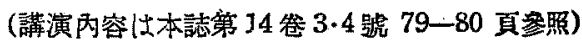

